\title{
A conversation with Lloyd Hollingsworth Smith Jr.
}

W e are joined by Dr. Lloyd Hollingsworth Smith Jr., known to most of his friends as Holly (Figure 1), for the next in our series of Conversations with Giants in Medicine. Smith is recognized for leading the University of California, San Francisco, Department of Medicine as its chairman for 21 years between 1964 and 1985 , whereupon his arrival, he quickly set about raising standards in patient care, teaching, and research. The full interview can be seen on the JCI website, http://www.jci. org/kiosk/cgm.

JCI: Can you tell me a little bit about your early days and your path to medical school?

Smith: I grew up during the depression in a small town in South Carolina. My grandfather had been the town doctor, and my father was a lawyer and cotton farmer. But a greater influence in my career choice was an uncle, Dr. Hugh Hollingsworth Smith, who had attended Johns Hopkins Medical School. He had a very interesting career at The Rockefeller Institute and later at the Rockefeller Foundation in helping to develop the yellow fever vaccine and later in proving its effectiveness in South America. After public high school, I entered Washington and Lee University, but the Pearl Harbor attack occurred in my first year. This remarkably altered the plans of all of my age group, most being soon in uniform. Those of us who were premed were told that we would be assigned to whatever medical school would accept us. In my case these were Harvard, Penn, and Johns Hopkins. I chose Harvard because my older brother was admitted there as well. I entered HMS in January 1944, at age 19.

JCI: Do you ground your interest in scientific lab research to that period?

Smith: Yes. When the war ended, I spent a year's fellowship in the Department of Physiology. This prepared me for an elective in my senior year with George W. Thorn, who was arranging the first American trials for the Kolff artificial kidney. The late John Merrill and I were assigned to set it up. At that time the kidney was a large revolving drum around which something like sausage casing was wrapped. A big tank held about 100 liters of dialysis fluid. Blood entered from an artery, but then after dialysis had to be pumped up to a reservoir before being returned via a vein. We did not have a non-wettable device into which to pump the dialyzed blood but then hit upon the idea of using condoms. I, as the youngest member of the team, was sent weekly to Joe Sparr's drug store to buy a gross. I was never again held in such high repute as a presumed Lothario as when carrying out this duty.

After graduation I served as intern and resident at the Mass General (1948-1950). Single members of the house staff lived in the hospital and were paid \$25 per month plus maintenance. It was an intense but rewarding boot camp-like experience.

JCI: At this point, you were sent to the Korean War?

Smith: I was first sent to the Walter Reed Army Institute of Research because of my background. We studied viral hepatitis and some genetic causes of renal function. But later, as a member of a team that was sent to Korea to investigate problems in care of the wounded, I found that a number of those most desperately injured were dying of acute kidney failure. I called back to Washington and obtained permission to obtain an artificial kidney for its first trial in a combat zone hospital.

JCI: Where did you land after your time in Korea?

Smith: By then it was clear that I needed much more training in basic science in order to pursue a career in academic medicine. I decided to spend the next three years in preparation - first at Harvard studying organic chemistry, then in NYC with DeWitt "Hans" Stetten (a pioneer in using isotopes to study metabolic pathways), and then at the Karolinska Institute in Stockholm. Of these, the year in NYC was the most important since Margaret Avery, my wife to be, returned there after having served for three years in the Middle East as a CIA agent. Our marriage of over 58 years has been enriched by a biomass of descendants -6 children and 17 grandchildren.

At this point I was scheduled to return to the MGH as chief medical resident, but I was very rusty in clinical medicine. Arrangements were made for me to be "de-rusted" for six months with the great Robert Loeb at Columbia before assuming that duty in 1956. Within two years thereafter, Walter Bauer, the charismatic chair at the MGH, asked me to become chief of the endocrine unit, despite my having no formal training in that discipline. Fortunately, a number of bright and capable young people joined me, many of whom have had distinguished subsequent careers.

I was able to spend a sabbatical year (1963-1964) at Oxford in the Department of Sir Hans Krebs. While there, I was asked to visit UCSF as a candidate for the chairmanship of the Department of Medicine. I did so about the time of my 40th birthday. Much to my surprise, I was offered the job at the time of this first visit. I accepted immediately and did not bargain.

JCI: So how did you set about transforming the department?

Smith: First, let me comment about what I found on arrival at UCSF, then celebrating its 100th birthday as the oldest medical school west of the Mississippi. The school could be evaluated in one of two alternate ways. Under close scrutiny, poor leadership, missed opportunities, lack of standards, and complacency were clearly evident. Viewed otherwise, however, UCSF was part of a great public university, some components of which were clearly eminent. Berkeley was a shining example. In booming California public support of education was exemplary. I was comfortable at Harvard, but why not take a chance, especially when young?

When I arrived in the fall of 1964, coming almost directly from Oxford, I began to take more careful stock. A colleague explained the tenure system to me, with the summary statement "While there's death, there's hope"! The department had only one member of the Association of American Physicians, which was doubled by my arrival. Research grants were few from the approximately 50 full-time members. The department now has about 550 members.

The earliest focus was on obtaining better leadership for the whole campus and for the clinical departments. In all of these initiatives, strong allies were found in the newly appointed chair of the Department of Surgery, J. Engleburt Dunphy, who had been one of my Harvard professors, and Julius Comroe, director of the Cardiovascular Research Institute. Space does not allow a summary of all of these actions, which greatly enhanced local standards 


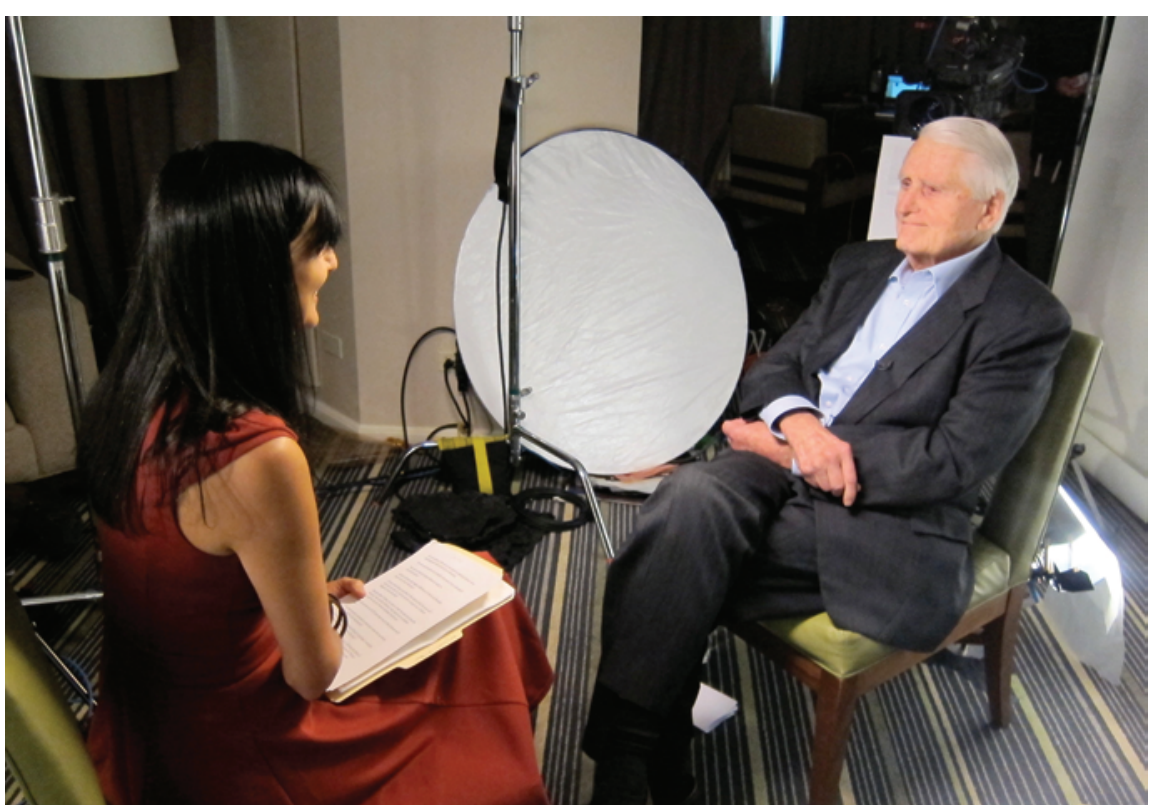

Figure 1

Ushma Neill interviewing Holly Smith on April 28, 2012. Image credit: Karen Guth.

and expectations. Newly recruited Bill Rutter and Gordon Tomkins quickly transformed the basic science community. A recent book, Paths to Innovation (1), documents the revolutionary research achievements at UCSF in the 1970s and 1980s recombinant DNA, oncogenes, and prions - the latter two awarded Nobel Prizes.

JCI: You also served on President Nixon's Presidential Scientific Advisory Committee (PSAC). What was that like?

Smith: I have never been sure why I was appointed to PSAC. It met about 8 times a year in the Executive Office Building with two charges: what could be done to advance American science, and, more important, what could science do to facilitate national policy? This being during the Vietnam War, the latter related largely to military topics. Nobel Prize winners in physics would discuss how to detect insurgents on the Ho Chi Minh trail or how to detect and follow Russian submarines. I did talk directly to Nixon about the "War on Cancer." Later PSAC was discontinued by Nixon because he did not like the advice offered.

JCI: Speaking of interesting people to work with, you also worked with the shah of Iran, who was trying to establish an academic medical center in Iran.

Smith: Well, I like to tell the joke sometimes that I worked with three of the most problematic people of our time, Richard Nixon, the shah, and Howard Hughes.
Now, working with shah, that's an exaggeration. I have been to Iran three times and spent some time teaching in Shiraz. I got a notice that the Minister of Science and Higher Education from Iran was coming to San Francisco to see me. So I went down to the hotel, and out came this dapper person surrounded by an entourage. He stuck out his hand and said, "Hi Holly," and I said, "My god who is that?" Well, it was His Excellency, Minister of Science and Higher Education; I'd known him as Chuck. He'd been a fellow at the Mass General years before. He got me involved, and later they set up a commission to advise the shah on developing a new imperial medical school. We met the shah briefly, and that was even in a rather formal setting.

JCI: You mentioned working with Howard Hughes. You served as chairman of the HHMI medical advisory committee, succeeding your former mentor George Thorn.

Smith: That was an interesting responsibility and a pleasure. My involvement with the HHMI Medical Advisory Board (MAB) extended over about two decades, starting in the early 1970s. Initially the budget was quite small, only about $\$ 4$ million annually for its total program. As a member of the $\mathrm{MAB}$, you were assigned some positions at your home institution - largely then at Harvard, Hopkins, Duke, Vanderbilt, and Seattle - and then UCSF. The IRS was pressing HHMI as a tax-free entity for not spending enough of its capital. I vividly remember receiving a call, "Come to Washington immediately. We must double the budget." So I hopped on the plane, came to Washington, carried some CVs, sat around a hotel room, and picked out Howard Hughes investigators just by passing around CVs. A couple of future Nobel Prize winners were selected by this method. Later, of course, the budget expanded by approximately 100 -fold and the whole process of selection became more formalized.

JCI: What advice would you give to people to have a successful academic medical career?

Smith: I rarely gave unsolicited advice. My mentors, Walter Bauer and George Thorn, were most effective by the standards they set in their personal careers. If pressed for advice by young colleagues, two ideas always came to mind. Think carefully of the long-term consequences of decisions, keeping in mind the wisdom of the internist's mantra, "Don't just do something, stand there." Also, carefully guard the frontier between commitment and obsession in our demanding lives. It is important to be a participant in the pageantry of one's times. There are no recorded deathbed statements, "I wish I had devoted more time to my profession."

JCI: You've got a real way with words you've been quoted as saying "Dress British; think Yiddish"; "Plan ahead. Always be concerned about the danger of mural dyslexia, the inability to read the handwriting on the wall"; "Organizations need to avoid chewing more than they bite off"; "Rather than wring our hands it would seem more sensible to find out whose hands to wring."

Smith: Most of these things that are attributed to me, I picked up from other people and passed them on. You kind of gather them over the years.

JCI: What do you think you would do if you were not an MD or a scientist?

Smith: I have never thought seriously of any other career. Our profession has so many rewarding alternative pathways. My own career has been rather strenuous at times but very fulfilling. It has been a privilege to be a part of UCSF as it has emerged as an eminent institution over the past generation.

\section{Ushma S. Neill}

1. Bourne HR. Paths to Innovation: Discovering Recombinant DNA, Oncogenes, and Prions, in One Medical School, Over One Decade. Berkeley, California, USA: University of California Press; 2011. 